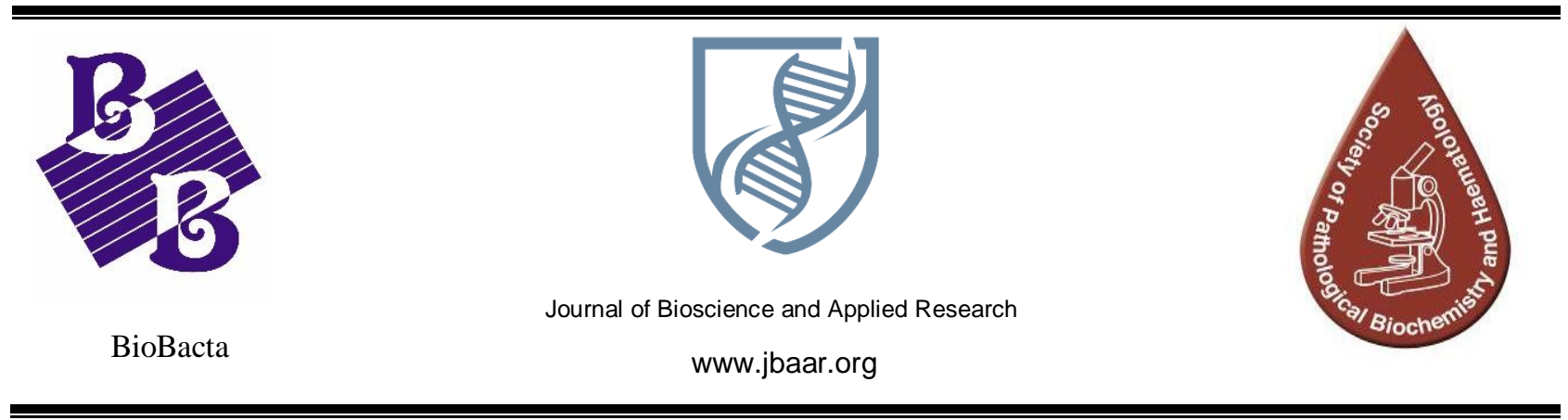

\title{
RBC Alloimmunization in Sudanese Multi-transfused Patients
}

\author{
Hager Elkobani ${ }^{1}$, Sahar Elbager $^{1 *}$, Magdi A. Bayoumi ${ }^{2}$ \\ ${ }^{1}$ Faculty of Medical Laboratory Sciences, University of Medical Sciences and \\ Technology (UMST), Sudan. \\ ${ }^{2}$ Faculty of Medical Laboratory Sciences, Ibn Sina University, Sudan. \\ *Corresponding author: saharelbager@gmail.com
}

Received 13/1/2020; Accepted 22/2/2020

DOI: 10.21608/jbaar.2020.115765

\begin{abstract}
:
Background: Blood transfusions are a life-saving measure to replace blood lost through severe bleeding or as a life-saving treatment for various hematological conditions. Blood transfusions are high-risk procedures. One of these risks is alloimmunization. Alloimmunization is an immune response to foreign antigens after exposure to genetically different cells or tissues. Alloimmunization is a frequent undesirable outcome of a blood transfusion. In this study, we investigated the frequency of alloimmunization and the factors associated with the development of antibodies infrequently transfused patients. Materials and Methods: A descriptive cross-sectional study carried out in Khartoum, Sudan between November 2017 and March 2018. The study population included 97 multi-transfused patients (Solid tumors, 41; Sickle cell anemia, 31; Leukemia; 25), 52 males and 45 females whose ages ranged between 3-81 years and each subject received a minimum of 2 units of RBCs. The number of blood units transfused varied among patients from 2 to over 20 units depending on the underline disease treatment needs. Antibody screen was performed using four-cell commercially prepared Grifols reagent RBCs and gel impregnated with antihuman globulin. Results: The overall alloimmunization frequency was $22.7 \%$. The alloimmunization frequency in Sickle cell anemia patients was $29.0 \%$, solid tumors patients; $21.9 \%$, and $16.0 \%$ in leukemic patients. Alloimmunization frequency was independent of the number of units transfused or gender ( $p$ value $=0.071,0.942$ ), respectively. Conclusion: Sudanese multi-transfused patients have higher rates of alloimmunization compared to other countries. It is our recommendation that pretransfusion protocols must include antibody screening. Timely antigen typing of donor's blood and to transfuse only antigen-negative blood.
\end{abstract}

Keywords: Antibody screen Test, Leukemia, SCD, Solid Tumors, Sudan, Transfusion, RBC Alloimmunization. 


\section{Introduction:}

Red blood cell (RBC) alloimmunization is the development of antibodies against non-self-antigens on $\mathrm{RBCs}$ in response to the exposure of genetically different cells which is a frequent complication in repeated RBC transfusions and pregnancy (Zimring et al., 2011, Mota, 2013). The process of alloimmunization is a complex and multifactorial immunological phenomenon. Factors that contribute to the development of alloantibodies include the antigenic difference between donors' and recipients' RBCs, the recipients' immune status, as well as the effect of the allogeneic blood transfusions on the recipient's immune system (Davari and Soltanpour, 2016, Saied et al., 2011, El Sewefy et al., 2014). Alloimmunization may result in; difficulty finding compatible RBC units, transfusion reactions, or platelet refractoriness, and in pregnancy, it is known to cause hemolytic disease of the fetus and newborn (HDFN). Alloimmunization complicates and limits life-saving transfusion therapy and may contribute to the morbidity and mortality of prospective blood transfusions' patients ( Tangvarasittichai S. S., 2017, Lindenburg et al., 2012, Nickel et al., 2016). Compatibility testing to ensure properly selected blood products cause no harm to the recipient should be performed to decrease the risk of alloimmunization (British Committee for Standards in et al., 2013, World Health Organization. Blood Transfusion Safety, 2001). The main tests used in compatibility testing according to the WHO guidelines are $\mathrm{ABO}$ and $\mathrm{RhD}$ grouping on patient and donors, antibody screening on patients, and crossmatching between serum of patient and red cells of the donor (British Committee for Standards in et al., 2013, World Health Organization. Blood Transfusion Safety, 2001).

Compatibility tests for RBC transfusion in Khartoum State include only ABO/D testing and a cross-match of a donor cell with patient serum. Antibody screen, antibody identification and the transfusion of antigennegative RBC units protocol are not followed which can result in a higher incidence of $\mathrm{RBC}$ alloimmunization resulting in delayed hemolytic transfusion reactions. Which in turn results in higher morbidity and mortality rates. Safe blood transfusion is a global issue and it is one of the WHO Sustainable Development Goals by 2030 (World Health Organization. Regional Office for the Western. Sustainable development goals (SDGs) : Goal 3 2016).

\section{Material and Methods:}

\section{Study design and study population}

A descriptive cross-sectional study carried out between November 2017 and March 2018 in patients receiving multiple transfusions and attending hematology and/or oncology clinics in Khartoum State. A total of 97 patients (52 males and 45 females, 3-81 years old, mean age $24.74 \pm 18.2$ years who received packed RBCs were included in the study. Participant's demographic data are given in Table 1 .

The study was approved by SUMASRI International Review Board (SIRB) at the University of Medical Sciences and Technology (UMST) and by Khartoum State Ministry of Health Research Department. The purpose and objectives of the study were explained to the patients. Written informed consent was obtained from all participants prior to enrolment into the study.

\section{Inclusion criteria:}

Patients over 2 years of age who received 2 units of blood or more during the past year.

\section{Exclusion criteria:}

The patient who is younger than two years or has received less than two units of packed $\mathrm{RBC}$ within the past year and multigravida females.

\section{Procedures:}

Five milliliters of venous blood were collected in ethylenediaminetetraacetic acid (EDTA) anticoagulant tube. The plasma was separated and stored in the freezer at $-20^{\circ} \mathrm{C}$ and analyzed weekly. The red cells were used for $\mathrm{ABO}$ grouping, $\mathrm{Rh}$ grouping. The stored plasma was thawed and used for antibody screening by gel technology using Grifols Gel Card System impregnated with antihuman globulin. The patient's 
plasma was combined with group $\mathrm{O}$ reagent red cells to allow for antigen/antibody interaction in the upper chamber of the microtube containing antiglobulin. Specimens were incubated at $37^{\circ} \mathrm{C}$ for 15 minutes. Gel cards were then centrifuged, and reactions were reported following the manufacturer's guidelines. The gel card method is based on the principle of variance passage of agglutinated and free red cells through a dextran acrylamide gel microtube column during centrifugation. Agglutinated red cells become trapped in or above the column. Un-agglutinated red cells settled at the bottom of the tube and no visible agglutination in the rest of the column.

\section{Data Management and Statistical Analysis}

Data were analyzed using Statistical Package for the Social Sciences 12.0, SPSS. Data was summarized graphically (frequency tables) and numerically (mean and standard deviation).

Table (1) Participant's demographic data

\begin{tabular}{lc}
\hline Parameters & $(\mathbf{n = 9 7})$ \\
\hline Age (range, mean \pm SD) & $3-81(25.37 \pm 18.1)$ \\
Gender & $52(53.6 \%)$ \\
Male & $45(46.4 \%)$ \\
Female & \\
Diagnosis & $31(32.0 \%)$ \\
Sickle cell anemia & $41(42.3 \%)$ \\
Solid tumors & $25(25.7 \%)$ \\
Leukemia & \\
Number of blood units transfused & $59(60.8 \%)$ \\
$2-4$ & $27(27.8 \%)$ \\
5 to 10 & $2(2.1 \%)$ \\
11 to 15 & $3(3.1 \%)$ \\
16 to 20 & $6(6.2 \%)$ \\
More than 20 & \\
\hline
\end{tabular}

\section{Results :}

The overall alloimmunization frequency was $22.7 \%$ (22 /97). On considering the clinical diagnosis that led to transfusions, variations in the alloimmunization rates were observed in each of the different groups. The alloimmunization frequency in SCD patients was 29.0 \% (9/31), $21.9 \%$ (9/41) among patients with solid tumors and $16.0 \%$ (4 of 25) in leukemic patients. 
Table (2) Frequency of alloimmunization by diagnosis

\begin{tabular}{lcc}
\hline Diagnosis $(\mathbf{n}=97)$ & Positive \# (\%) & Negative \# (\%) \\
\hline Sickle cell anemia $(\mathrm{n}=31)$ & $9(29 \%)$ & $22(71 \%)$ \\
Solid tumors $(\mathrm{n}=41)$ & $9(21.9 \%)$ & $32(78.1 \%)$ \\
Leukemia $(\mathrm{n}=25)$ & $4(16.0 \%)$ & $21(84.0 \%)$ \\
Total & $22(22.7 \%)$ & $75(77.3 \%)$ \\
\hline
\end{tabular}

In the present study, a number of packed cell units transfused ranged from 2 to more than 20 units. There was no statistically significant correlation between the number of units transfused and the rate of alloimmunization $(p$ value $=0.071)$. Table 3

Table (3) Frequency of alloimmunization according to number of units transfused

\begin{tabular}{cccc}
\hline Number of units transfused & Positive \# (\%) & Negative \# (\%) & Total \# (\%) \\
\hline Less than 5 & $12(20.3 \%)$ & $47(79.7 \%)$ & $59(60.8 \%)$ \\
5 to 10 & $5(18.5 \%)$ & $22(81.5 \%)$ & $27(27.8 \%)$ \\
11 to 15 & $0(0 \%)$ & $2(100.0 \%)$ & $2(2.1 \%)$ \\
16 to 20 & $1(33.3 \%)$ & $2(66.7 \%)$ & $3(3.1 \%)$ \\
More than 20 & $4(66.7 \%)$ & $2(33.3 \%)$ & $6(6.2 \%)$ \\
Total & $22(22.7 \%)$ & $75(77.3 \%)$ & $97(100 \%)$ \\
& P value 0.071 & & \\
\hline
\end{tabular}

No statistical difference in the rate of alloimmunization between males and females. Of 52 males, 11 (21.2\%) developed alloantibodies, and out of 45 females, $11(24.4 \%)$ developed alloantibodies; ( $p$ value $=0.942$ ). Table 4

Table (4) Frequency of alloimmunization according to gender

\begin{tabular}{lccc}
\hline Gender & Positive \# (\%) & Negative \# (\%) & Total \# (\%) \\
Male & $11(21.2 \%)$ & $41(78.8 \%)$ & $52(53.6 \%)$ \\
Female & $11(24.4 \%)$ & $34(75.6 \%)$ & $45(46.4 \%)$ \\
Total & $22(22.7 \%)$ & $75(77.3 \%)$ & $97(100 \%)$ \\
& \multicolumn{3}{c}{ P value 0.942} \\
\hline
\end{tabular}




\section{Discussion:}

The overall alloimmunization frequency detected in this study was $22.7 \%$ which consistent with $22.6 \%$ alloimmunization rate reported in Saudi multitransfused patients (Gader et al., 2008). However, this rate is higher than previously reported rates in multitransfused patients in other African countries which ranged between $1 \%$ to 10.3 (Ndahimana et al., 2013, Mangare et al., 2015, Alick and Nathan 2014). The higher rate of alloimmunization observed in our study may be explained by the diverse ethnicity in our population, donors and recipients alike.

The higher rate of alloimmunization was observed among SCD patients (29.0\%). This high rate is comparable to a study in Egyptian SCD patients (Aly et al., 2012), where the rate was $21.4 \%$. In contrast, lower alloimmunization rates of $2.9 \%, 4.1 \%, 4.4,6.1 \%$, $9.3 \%, 10 \%$, and $18.7 \%$ have been reported in SCD patients in, Kenya (Mangare et al., 2015), Tanzania (Meda et al., 2014), Mali (Diarra et al., 2013), Uganda (Natukunda et al., 2010), Nigeria (Ugwu et al., 2015) Congo Nigeria (Kangiwa et al., 2015a) respectively. These African countries have a more ethnically homogeneous population in comparison to Sudan. Where donors and recipients are racially more homogeneous.

In Sudan, Abass et al reported the incidence of alloimmunization among SCD patients was only $4 \%$ (Mohammed Abbas, 2013), compared to our study (29\%), the law percent may be explained by the donor's selection bias as $45 \%$ of donors were relatives of the transfusions recipients.

Our data indicate that $21.9 \%$ of patients with Solid tumors were alloimmunization positive. In a study of 44 Ugandan patients with Solid tumors, alloimmunization was reported at a frequency of $11.4 \%$ (Natukunda et al., 2010). While in Kenyan Solid tumors patients no alloimmunization detected (Mangare et al., 2015) where there was less heterogeneity among donors and patients.
In this study; leukemic patients had an alloimmunization frequency of $16 \%$, which is similar to the $15 \%$ found by (Sanz et al., 2013) and $11 \%$ found by (Leisch et al., 2017).

In this study, no statistically significant association observed between number units transfused and the development of alloantibodies as well as no difference in the incidence in males versus females. These findings are consistent with previous reports that have shown no association between the number of units transfused and the alloimmunization frequency (Mangare et al., 2015, Baby et al., 2010), gender (Mohammed Abbas, 2013, Kangiwa et al., 2015b, elDanasoury et al., 2012), conversely some studies reported association between the alloimmunization frequency and the number of units transfused (Natukunda et al., 2010) and females gender (Verduin et al., 2015, Saied et al., 2011).

In conclusion, our study indicates that frequently transfused Sudanese patients are prone to the development of alloantibodies. The presence of alloantibodies in the serum of transfusion-dependent and/or frequently transfused patients makes it difficult to provide timely compatible blood and it is costly. At times, it is difficult to provide antigen-negative blood to patients who have developed multiple alloantibodies due to the scarce supply and high demand. It is important to prevent the development of alloantibodies exercising proper detection and typing prior to any elective blood transfusion. It is equally important to detect any alloantibodies in a timely fashion to provide antigen-negative blood when indicated.

\section{References}

ALY, R., EL-SHARNOBY, M. R. \& HAGAG, A. A. 2012. Frequency of red cell alloimmunization in patients with sickle cell anemia in an Egyptian referral hospital. Transfusion and Apheresis Science, 47, 253-257.

BABY, M., FONGORO, S., CISSÉ, M., GAKOU, Y., BATHILY, M., DEMBÉLÉ, A. K., MAÏGA, M. K., 
TOUNKARA, A. \& DIALLO, D. A. 2010.

Frequency of red blood cell alloimmunization in polytransfused patients at the university teaching hospital of Point G, Bamako, Mali. Transfusion clinique et biologique : journal de la Societe francaise de transfusion sanguine, $17,218-222$

BRITISH COMMITTEE FOR STANDARDS IN, H., MILKINS, C., BERRYMAN, J., CANTWELL, C., ELLIOTT, C., HAGGAS, R., JONES, J., ROWLEY, M., WILLIAMS, M. \& WIN, N. 2013. Guidelines for pre-transfusion compatibility procedures in blood transfusion laboratories. British Committee for Standards in Haematology. Transfusion medicine (Oxford, England), 23, 3-35.

DAVARI, K. \& SOLTANPOUR, M. S. 2016. Study of alloimmunization and autoimmunization in Iranian $\beta$-thalassemia major patients. Asian journal of transfusion science, 10, 88-92.

DIARRA, A. B., GUINDO, A., KOURIBA, B., DORIE, A., DIABATÉ, D. T., DIAWARA, S. I., FANÉ, B., TOURÉ, B. A., TRAORÉ, A., GULBIS, B. \& DIALLO, D. A. 2013. Sickle cell anemia and transfusion safety in Bamako, Mali. Seroprevalence of HIV, HBV and HCV infections and alloimmunization belonged to $\mathrm{Rh}$ and Kell systems in sickle cell anemia patients. Transfusion clinique et biologique : journal de la Societe francaise de transfusion sanguine, 20, 476-481.

EL-DANASOURY, A. S., EISSA, D. G., ABDO, R. M. \& ELALFY, M. S. 2012. Red blood cell alloimmunization in transfusion-dependent Egyptian patients with thalassemia in a limited donor exposure program. Transfusion, 52, 43-47.
EL SEWEFY, D., AL FEKY, M., ABDEL FATAH, M., EL SAKHAWY, Y., RAGAB, I. \& EL SAYED, H. T. 2014. Clinically significant red blood cell antibodies in multitransfused Egyptian thalassemic patients. The Egyptian Journal of Haematology, 39, 171-176.

GADER, A. G., AL GHUMLAS, A. K. \& AL-MOMEN, A. K. 2008. Transfusion medicine in a developing country - alloantibodies to red blood cells in multi-transfused patients in Saudi Arabia. Transfus Apher Sci, 39, 199-204.

KANGIWA, U., IBEGBULAM, O., OCHENI, S., MADU, A. \& MOHAMMED, N. 2015a. Pattern and prevelence of alloimmunization in multiply transfused patients with sickle cell disease in Nigeria. Biomarker Research, 3, 26.

KANGIWA, U., IBEGBULAM, O., OCHENI, S., MADU, A. \& MOHAMMED, N. 2015b. Pattern and prevelence of alloimmunization in multiply transfused patients with sickle cell disease in Nigeria. Biomarker research, 3, 26-26.

LEISCH, M., WEISS, L., LINDLBAUER, N., JUNGBAUER, C., EGLE, A., ROHDE, E., GREIL, R., GRABMER, C. \& PLEYER, L. 2017. Red blood cell alloimmunization in 184 patients with myeloid neoplasms treated with azacitidine A retrospective single center experience. Leukemia Research, 59, 12-19.

LINDENBURG, I. T., SMITS-WINTJENS, V. E., VAN KLINK, J. M., VERDUIN, E., VAN KAMP, I. L., WALTHER, F. J., SCHONEWILLE, H., DOXIADIS, I. I., KANHAI, H. H., VAN LITH, J. M., VAN ZWET, E. W., OEPKES, D., BRAND, A., LOPRIORE, E. \& GROUP, L. S. 2012. Long-term neurodevelopmental outcome after intrauterine transfusion for hemolytic disease of the fetus/newborn: the LOTUS study. 
American journal of obstetrics and

gynecology, 206, 141.e1-141.e1418.

MANGARE, C., MBUGUA, A., MATURI, P., RAJAB, J., BLASCZYK, R. \& HEUFT, H.-G. 2015. Red cell allo- and autoimmunisation in transfused sickle cell and cancer patients in Kenyatta National Hospital, Nairobi, Kenya. African journal of laboratory medicine, 4, 297-297.

MEDA, E., MAGESA, P. M., MARLOW, T., REID, C., ROBERTS, D. J. \& MAKANI, J. 2014. Red Blood Cell Alloimmunization in Sickle Cell Disease Patients in Tanzania. East African journal of public health, 11, 775-780.

MOHAMMED ABBAS, A. B., NASRELDIN JIEFRI, ADIL MERGANI. 2013. Red Blood Cell

Alloimmunization among Sudanese Homozygous Sickle Cell Disease Patients. American Journal of Medicine and Medical Sciences 3 61-67.

MOTA, M. A. 2013. Red cell and human leukocyte antigen alloimmunization in candidates for renal transplantation: a reality. Rev Bras Hematol Hemoter, 35, 160-1.

MWAMBUNGU ALICK, S. N. 2014. Frequency and Distribution of RBC Alloantibodies among Transfused Patients at Ndola Central Hospital , Zambia. Int J Sci Res 3, 86-9.

NATUKUNDA, B., SCHONEWILLE, H., VAN DE WATERING, L. \& BRAND, A. 2010. Prevalence and specificities of red blood cell alloantibodies in transfused Ugandans with different diseases. Vox sanguinis, 98, 167171.

NDAHIMANA, E., GOTHOT, A., GÉRARD, C., SENYANA, F., R'ZIK, S., MUKABAYIRE, O. \& MUTESA, L. 2013. RISK OF RED BLOOD CELL ALLOIMMUNISATION IN RWANDA: ASSESSMENT OF PRETRANSFUSION
CROSSMATCH TECHNIQUES USED IN

DISTRICT HOSPITALS. East African medical journal, 90, 124-129.

NICKEL, R. S., HENDRICKSON, J. E., FASANO, R. M., MEYER, E. K., WINKLER, A. M., YEE, M. M., LANE, P. A., JONES, Y. A., PASHANKAR, F. D., NEW, T., JOSEPHSON, C. D. \& STOWELL, S. R. 2016. Impact of red blood cell alloimmunization on sickle cell disease mortality: a case series. Transfusion, 56, 107114

S., T. 2017. Impact of alloimmunization on transfusion-dependent patients. . Ann Adv Chem, 1, 070-082.

SAIED, D. A., KADDAH, A. M., BADR ELDIN, R. M. \& MOHASEB, S. S. 2011. Alloimmunization and erythrocyte autoimmunization in transfusiondependent Egyptian thalassemic patients. Journal of pediatric hematology/oncology, 33, 409-414.

SANZ, C., NOMDEDEU, M., BELKAID, M., MARTINEZ, I., NOMDEDEU, B. \& PEREIRA, A. 2013. Red blood cell alloimmunization in transfused patients with myelodysplastic syndrome or chronic myelomonocytic leukemia.

Transfusion, 53, 710-715.

UGWU, N., AWODU, O., BAZUAYE, G. \& OKOYE, A. 2015. Red cell alloimmunization in multitransfused patients with sickle cell anemia in Benin City, Nigeria. Nigerian Journal of Clinical Practice, 18, 522-526.

VERDUIN, E. P., BRAND, A., MIDDELBURG, R. A. \& SCHONEWILLE, H. 2015. Female sex of older patients is an independent risk factor for red blood cell alloimmunization after transfusion. Transfusion, 55, 1478-1485.

WORLD HEALTH ORGANIZATION. BLOOD TRANSFUSION SAFETY, T. 2001. The Clinical 
use of blood : handbook. Geneva: World Health Organization.

WORLD HEALTH ORGANIZATION. REGIONAL OFFICE FOR THE WESTERN, P. 2016. Sustainable development goals (SDGs) : Goal 3. Target 3.4 : By 2030 , By 2030 , reduce by one third premature mortality from non-communicable diseases through prevention and treatment and promote mental health and well being [poster]. Manila : WHO Regional Office for the Western Pacific.

ZIMRING, J. C., WELNIAK, L., SEMPLE, J. W., NESS, P. M., SLICHTER, S. J. \& SPITALNIK, S. L. 2011. Current problems and future directions of transfusion-induced alloimmunization: summary of an NHLBI working group. Transfusion, 51, 435-41. 